\title{
Relationship between Firm Age and Financial Leverage with Dividend Policy
}

\author{
Mohammad Tamimi \\ Accounting Department, Dezful Branch, Islamic Azad University, Dezful, Iran \\ E-mail: tamimi.mohammad@gmail.com \\ Nasrollah Takhtaei \\ Accounting Department, Dezful Branch, Islamic Azad University, Dezful, Iran \\ E-mail: nasrollah_takhtaei@yahoo.com \\ Fatemeh Malchi (Correspondence Author) \\ Department of Accounting, Payame Noor University, I.R of Iran \\ E-mail: Fatemeh.Malchi@gmail.com
}

Received: July 2, 2014 Accepted: July 30, 2014 Published: December 1, 2014

doi:10.5296/ajfa.v6i2.5910 URL: http://dx.doi.org/10.5296/ajfa.v6i2.5910

\begin{abstract}
In this study, the effect of the financial leverage the age of the company on the policies of the profit distribution of the company has been investigated. In this case, two hypotheses have been developed. In the first hypothesis, the effects of the age of the company and also in second hypothesis the effects of the financial leverage on the policies of profit distribution of the company have been investigated. Sample firms are the manufacturing companies accepted in Tehran Stock Exchange (TSE) over the period from 2005 to 2011. In order to determine the sample firms, systematic sampling has been used and finally 92 companies have been selected. To investigate the linear or non-linear relationship between company age and dividends, the square and the cube of the company age in empirical model of the research have been used. The results indicate a positive and significant relationship between company age and dividend ratio, but a negative and significant association between financial leverage and dividend.
\end{abstract}

Keywords: Profit, Dividend Policies, Financial Leverage, Company Age 


\section{Introduction}

The primary aim of financial accounting is presenting the useful information for the investors to predict the function of economic unit. The necessity to report the profit as an initial source for the investors deciding was usable well and the profit report in different ways such as presenting a basis for calculating tax, a criterion to evaluate the success of the function of the company, the level of the dividends, management of the profit distribution, management of an economic unit etc. helps the economics of the society. In addition, since the value of a company is related to the profits of the present and future, determining the profit has a significant importance (FASB, 1978).

Dividend policies are discussable from two very important aspects. From one viewpoint, dividend is an effective factor on the future investments of the companies; the more dividend, the less internal sources of the company in order to accomplish the investment projects and the more necessity to the financial sources out of the company, which this can affect the price of the stocks of the companies in the future. On the other hand, many of the company investors demand cash dividend. Therefore, the managers (with the aim of increasing the investors property) should make an alignment in different interests of the stockholders either not to lose the profit investing opportunities, or to pay the cash profit required by the stockholders. Accordingly, the decisions in distribution of profit which are taken by the managers of companies are very important and sensitive (Mehrani, 2004).

The stockholders need some information to determine the value of securities for deciding about buying and selling the companies' stocks. The main role of accounting is preparing the information for the users to determine the dividend politics of the companies. The investors can make better decisions about buying or selling the stocks, using the accounting information in the case of dividend policies. According to what has been mentioned above, the effect of the age of the company and financial leverage on dividend policies of the company is significant and this study has been done in this case. Following this part, the literature review will be presented, then the hypotheses, methodology and the variables used in the study will be defined and finally the testing of the hypotheses and the results of the study will be presented.

\section{Literature review}

The dividend term usually refers to the cash or non-cash payments of the company income to the stockholders. The profit of the stocks may be paid as cash dividend or share dividend. Cash dividend is the most usual kind of transferring the returns from companies to the stockholders. The companies do not act in the same way in distributing their cash dividend and they have different policies. These policies can be various and have a range from the payment of the minimum of the cash dividend appointed in the regulations to the payment of the whole profit of the company and even more than the annual profit as the cash profit.

The leverage includes the warnings indicating the managers' information about the investing opportunities. The theories of the investment structure express that the managers of the companies with appropriate opportunities for growth should choose a less leverage, because 
if they increase their external debt, will not be able to use the advantages of their investing opportunities and therefore there will be a negative relationship between the future growth and the leverage, since the managers of the companies with high opportunity to grow will choose the low leverage. Such results can be in regressions which control the growth opportunities.

In economics and management, the age of the companies and institutions is divided into the steps. In the literature of these sciences, some models have been presented for the age of the companies which in the framework of these models, the companies and the institutions follow a specific policy considering every step of their economic age. These policies will be reflected in the accounting information of the companies in different ways (Ghorbani, 2006). In the field of accounting, some of the researchers have paid attention to the study of the effect of the age cycle of the company on the accounting information as well (Black, 1998; Jenkins, Kane, and Velury, 2004; Ahmad and Javid, 2009). These researchers have expressed four steps to describe the age cycle of the company as (1) the introduction stage, (2) the growth stage, (3) the maturity stage, and (4) the decline stage.

For the first time, Lintner (1956) investigate the analysis of the dividend policies using both empirical and survey approaches. His study in financial literature led to introducing 15 effective variables on dividend policies such as company size, investing expenses, tendency to use external financing, share dividend, earnings persistence and ownership (Lintner, 1956). Wang et al. (2011) examine the dividend policies and the age cycle hypothesis in Taiwanese stock exchange market. The result of their study indicated that the payment of the stocks profit in new business units with high growth ability and low profitability will lead to the more distribution of share dividend versus cash dividend. Also, it indicated that in business units with low growth ability and high profitability will lead to the more distribution of cash dividend versus share dividend (Wang et al., 2011). Using data from a sample of 25 companies during 1999 to 2009 on the Greek stock exchange, Afza and Mirza (2010) indicate that the dividend policies and its treatment is the most important for the investors (Afza and Mirza, 2010). In another study, Almazan et al. (2010) also examined the effect of the financial leverage on the dividend policies in the companies of Karachi. The result of their study indicated a negative and significant relationship between financial leverage and amount of divisible profit. Additionally, their study showed that the changes of net income and the returns of cash dividend are effective on the dividend policies (Almazan et al., 2010).

The first study in the field of the age cycle of the companies in accounting area was conducted by Anthony and Ramesh (1992). After classifying the companies into growth, maturity and decline steps, they investigated the relationship between the function criteria such as increasing of selling and investment expenses with the price of the stock market. The purpose in their study was investigating the reaction of the market to the accounting information in different steps of the age cycle. The findings indicates that there is a significant relationship between the function criteria and the price of the stock market in different steps of the age cycle, so that the amount of the relationship of the selling growth criteria and investing expenses from introduction to decline steps has a downward movement (Anthony and Ramesh, 1992). 
Stepanyan (2011) investigates the age cycle of the business unit and the type of the dividend payment. In this study three different groups of business units distributing cash including redemption of shares, cash dividend and a combination of the cash dividend and redemption of shares, are considered. Redemption of shares in quick growth step is very probable and is a sign of the quality of the business unit for the investors. Cash dividend payment to the stockholders increases in matured business units. The managers' tendency also increases for expanding or preserving the size of the business units to the welfare of the stockholders. Finally, using the combination of the cash dividend and redemption of shares will be in more matured business units. This study shows that the age cycle of the companies is one of the most important reasons for choosing the methods of the dividend payment (Stepanyan, 2011).

\subsection{Hypotheses development}

This study aims to determine the amount of the effect of the financial leverage and the age of the company on the profit division politics which is based on Afza and Mirza (2010) research and according to the presented model. The special goal is to clarify whether there is a meaningful relationship between the age of the company and the financial leverage with the amount of the dividend in accepted companies in Tehran stock exchange. Considering what has been mentioned, the hypotheses in this study have been designed as follows and will be tested:

$H_{1}$ : there is a significant relationship between dividend policy and company age.

$\mathrm{H}_{2}$ : there is a significant relationship between dividend policy and financial leverage.

\section{Research Design}

This study is a kind of quasi-experimental research in the field of proving researches of accounting which will be accomplished using multivariable regression method and the econometrics patterns. The hypotheses of the study will be tested based on pooling statistical method using Eviews software. Considering that the Iranian capital market has a large fluctuation during the research, in order to increase the reliability of the results, the research hypotheses will be tested cross- sectionally.

\subsection{Data Collection and Sample selection}

The sample firms of this study are the companies accepted in Tehran stock exchange for 7 years during the period from 2005 (2005/03/21, the beginning of fiscal year in Iran) to 2011 (2012/03/20, the end of fiscal year in Iran), which during this period perform as a member in securities exchange. The data is balanced using the following conditions: The samples should not be included in the sector of financial services, investing and insurance companies but manufacturing companies. The companies should be in securities exchange during the years considered in this study. Their transactions shouldn't be stopped more than three months and there should be the available data required for this study during the mentioned time and have annual year ending to the end of financial year (20XX/03/20). The considered companies should not be loss companies and also they should pay dividend at least for three years 
consecutively. According to the criteria, 92 companies have been selected which their information has been collected through Tehran stock exchange and Tadbirpardaz database.

\subsection{Variables definition}

The variables of this research are dependent, independent and control variables which are defined as under:

\subsubsection{Dependent variable}

Dividend is the payable profit to the stockholders which is acquired through dividing dividend over number of outstanding shares at annual general meeting.

\subsubsection{Independent variables}

1. Company age ( $A G E$ ) is the number of the activity years of the company which is acquired through the difference between the current year and the year of the establishing the company (John and Williams, 1985).

2. Financial leverage ( $L E V$ ) is defined as the total debts divided by total assets of the company at the end of fiscal year.

3. Additionally, control variables have been used to equalize the companies through the effective factors in this study. These variables include earnings per share and company size which according to DeAngelo (1981) is measured as the natural logarithm of the total assets at the end of the financial period (DeAngelo, 1981).

The earnings per share (EPS) is the part that indicate firm's periodical performance based on ownership of the shareholders. This proportion indicates the revenue of each common stock of the company and is calculated through dividing net profit by the number of the common stocks.

\subsection{Model specifications}

Based on the mentioned explanations and in order to test the hypotheses, the research model is presented as follows:

$$
D P O_{i t}=\beta_{0}+\beta_{1}\left(A G E_{i t}\right)+\beta_{2}\left(A G E_{i t}\right)^{2}+\beta_{3}\left(A G E_{i t}\right)^{3}+\beta_{4}\left(L E V_{i t}\right)+\beta_{5}\left(E P S_{i t}\right)+\beta_{6}\left(S I Z E_{i t}\right)+\varepsilon_{i t}
$$

Where;

DPO: $\quad$ Division payout,

AGE: $\quad$ Company age,

LEV: $\quad$ Financial leverage, 
EPS: $\quad$ Earnings per share,

SIZE: $\quad$ Company size,

$\varepsilon: \quad$ Error term,

\section{Results}

\subsection{Descriptive Statistics}

In order to do the current study, the collected data have been analyzed and then the results related to the descriptive statistics of the data, correlation coefficient stable, standard deviations, regression results regarding research hypothesis have been interpreted.

Table 1. Descriptive statistics of the variables

\begin{tabular}{lrrrrr}
\hline Variables & Minimum & Maximum & Mean & Median & Std.Dev \\
\hline DPO & 0.0000 & 1.2354 & 0.3865 & 0.4439 & 0.6529 \\
& & & & & \\
$A G E$ & 9.0000 & 54.0000 & 22.5438 & 23.4764 & 14.8602 \\
$A G E^{2}$ & 81.0000 & 2916.0000 & 1204.3690 & 1190.1600 & 143.9167 \\
$A G E^{3}$ & 729.0000 & 157464.0000 & 65891.7600 & 61439.9100 & 1426.5620 \\
LEV & 0.3681 & 0.9378 & 0.6237 & 0.6139 & 0.6894 \\
EPS & -1382.7800 & 7238.9300 & 894.2100 & 978.4400 & 28.8620 \\
SIZE & 4.2866 & 7.6894 & 5.4139 & & \\
\hline
\end{tabular}

Notes: DPO = Dividend payout; AGE = Age of company; $A G E^{2}=$ Square of company age; $A G E^{3}=$ Cube of age company; LEV = Financial leverage; EPS = Earnings per share; SIZE = Company size

\subsection{Pearson Correlation Matrix}

The study of correlation is a statistical way through which the order that a variable can be related to another variable linearly can be measured. The relationship between the variables of the research has been presented in table 2. The correlation coefficient between the independent variables applied in the model should not be large, because the correlation between independent variables in a model leads to the bias in the regression results. 
Table 2. Pearson Correlation Matrix

\begin{tabular}{lccccccc}
\hline Variables & $D P O$ & $A G E$ & $A G E^{2}$ & $A G E^{3}$ & LEV & EPS & SIZE \\
\hline$D P O$ & 1.0000 & & & & & & \\
$A G E$ & 0.2231 & 1.0000 & & & & & \\
$A G E^{2}$ & -0.0656 & 0.2108 & 1.0000 & & & & \\
$A G E^{3}$ & 0.1904 & 0.0362 & 0.2472 & 1.0000 & & & \\
$L E V$ & -0.1178 & -0.3514 & -0.0913 & 0.1087 & 1.0000 & & \\
$E P S$ & 0.2302 & -0.0012 & 0.1436 & 0.0043 & -0.0346 & 1.0000 & \\
$S I Z E$ & 0.3401 & 0.0212 & -0.0264 & 0.0658 & 0.1456 & 0.1406 & 1.0000 \\
\hline
\end{tabular}

Notes: DPO = Dividend payout; AGE = Age of company; $A G E^{2}=$ Square of company age; $A G E^{3}=$ Cube of age company; LEV = Financial leverage; EPS = Earnings per share; SIZE = Company size

\subsection{Regression Results}

As mentioned before, the main aim of the study is to test of the relationship between the age of the company and the proportion of the financial leverage with the dividend politics. In this case two hypotheses have been developed. Following, the results of the test of the first and second hypotheses have been presented. The test of the significant coefficients is what the researcher is going to find. The results of regression model significance and coefficients significance using pool data method are presented in table 3 for 2005-2011. As it is observed in the table, F-statistic at the level of $99 \%$ confidence is significant. Therefore, the model of the study is significant generally and the independent and control variables are able to explain variations in the dependent variable of the model. In addition, the determination coefficient is equal to 0.02293 . This number indicates that about $23 \%$ of the changes in the dependent variable, that is the proportion of the dividend, are explained by the changes in the independent and control variables of the model and $77 \%$ of the changes are related to other factors which are not considered in this study. In addition to the determination of the coefficients significance, the direction of the effect of the coefficients on the dependent variable should be determined as well. The related statistic to determine the significance of the coefficients is t-statistic. Generally, to investigate the model as a significant one, the $F$-statistic is also used. To test the null hypothesis, $t$-statistic is used. According to this if the p-value is less than 0.05 , the null hypothesis will be rejected and therefore, the alternative hypothesis will be accepted. Accepting the alternative hypothesis implies that there is a significant linear relationship between independent variables and dependent variable in the model. Therefore, if $\mathrm{Sig}(P$-Value $)<.05$, then $H_{0}$ will be rejected and otherwise $H_{1}$ will be accepted. According to our multivariable model, if the coefficient of each of the independent variables (i.e., $\beta$ ) is positive, the related independent variables will have a direct relationship with the dependent variable which is dividend of each stock and if the coefficient is negative, there will be an inverse relationship. 
Table 3. Multivariate Analysis

Dependent variable: Dividend payout (DPO)

\begin{tabular}{lcccc} 
Independent Variable & Parameter & Coefficient & t-statistics & $p$-value \\
\hline Intercept & $\beta_{0}$ & 0.0828 & 4.2316 & 0.0017 \\
$A G E$ & $\beta_{1}$ & 1.1138 & 4.8794 & 0.0153 \\
$A G E^{2}$ & $\beta_{2}$ & -0.3809 & -2.0267 & 0.0987 \\
$A G E^{3}$ & $\beta_{3}$ & 0.0626 & 3.3249 & 0.0000 \\
LEV & $\beta_{4}$ & -0.1729 & -4.0928 & 0.0048 \\
$E P S$ & $\beta_{5}$ & 1.0216 & 14.3269 & 0.0000 \\
SIZE & $\beta_{6}$ & 0.2674 & 2.8342 & 0.0413 \\
\hline Adjusted $R^{2}$ & & & 0.2293 \\
$F$-statistics & & & 6.4358 \\
$P$-value $(F)$ & & & 0.0000 \\
$D$-W $W$ & & & 1.9276 \\
\hline
\end{tabular}

Notes: DPO = Dividend payout; AGE = Age of company; $A G E^{2}=$ Square of company age; $A G E^{3}=$ Cube of age company; LEV = Financial leverage; EPS = Earnings per share; SIZE = Company size

\subsubsection{Result of First Hypothesis}

The first hypothesis of the research refers to the investigation of the relationship between the age of the company and the proportion of the dividend. In this hypothesis, the dependent variable is the proportion of the dividend and the independent variable is the age of the company. The age of the company is the duration between the year of the establishment of the company and the current year. Following Afza and Mirza (2010), the square and cube of the age of the company is also employed. The reason is finding out the linear or non-linear relationship between the dividend and the age of the company. Because the companies have age cycle and it is possible that the profits divided in the beginning of the establishment or the beginning of the entrance to the securities exchange among the stockholders be different from the amount of the division profits in maturity or growth steps or recession step. According to the results indicated in table 4, t-statistic is related to the AGE and its level of significance ( $p$-value) are 4.8794, 0.0153 respectively. Since the fact that the considered alpha for this study is 0.05 , the result will be that the age of the company with error level of $5 \%$ has a significant relationship with the proportion of the dividend. The variable coefficient of the AGE is positive. Therefore, the relationship between the age of the company and the dividend of the company is direct. In other words, increasing the age of the company in sample companies, the amount of the dividend of the considered companies will be increased as well. In AGE variable coefficient test it is observed that the resulted level of significance is more than 0.05. Therefore, it can be resulted that the square of the age of the company has insignificant relationship with the proportion of the dividend. According to the acquired results of the estimation of the model, the $t$-statistic related to AGE independent variable and its level of the meaningfulness ( $p$-value) are 3.3249 and 0.0000 respectively. These numbers indicate that the considered variable coefficient with $99 \%$ confidence level is significant. 
According to what has been mentioned above, the first hypothesis of the study is confirmed. The relationship between the age of the company and the proportion of the dividend is a linear relationship and the non-linear relationship (curve) is not confirmed. The reason can be explained as the sample companies of the study use the investing opportunities for increasing the profit at the beginning of the establishment or at the beginning of the entrance to the securities exchange and in the future more profits will be divided. The results of the test of this hypothesis are not consistent with the results of the Afza and Mirza (2010). They found a non-linear relationship between the age of the company and the dividend in Pakistani companies.

\subsubsection{Result of Second Hypothesis}

The second hypothesis refers to the investigation of the relationship between the financial leverage and the proportion of the dividend. In this hypothesis, the dependent variable is the proportion of the dividend and the independent variable is the proportion of the financial leverage. The financial leverage measured as the ratio of debt over assets indicates the financial risk of the company. According to the results of the table 4, t-statistic is related to the financial leverage (LEV) as independent variable and its level of significance ( $p$-value) is -4.0928 and 0.00048 respectively. Since the acquired level of significance is less than 0.01 , it can be resulted that the ratio of the financial leverage with $99 \%$ confidence level has a significant relationship with the ratio of the dividend. The coefficient sign of financial leverage (LEV) is also negative. Therefore, there is an inverse relationship between the ratio of the financial leverage and the dividend of the company. In other words, as the risk and the financial leverage increase (decrease) in sample companies, the amount of the dividend decreases (increases). The results of the second hypothesis are consistent with Afza and Mirza (2010).

\section{Discussion and Conclusion}

The main aim of the current study is to investigate the relationship between the age of the company and the ratio of financial leverage with the ratio of the dividend. Thus, two hypotheses were developed. In the first hypothesis, the effect of the age of the company on the dividend politics and in the second hypothesis the effect of financial leverage on the dividend politics of the company was investigated. The sample consists of 92 listed companies on Tehran stock exchange in manufacturing industry during 2005-2011.The pooled data analysis and multivariable regression method were used to test the hypotheses. In order to investigate the linear or non-linear relationship between the age of the company and the dividend, the square and the cube of the age of the company were also used in the empirical model of the study. The results of the first hypothesis were inconsistent with the results of study conducted by Afza and Mirza (2010). They found a non-linear relationship between the age of the company and the dividend in Pakistani firms. The results of the second hypothesis indicate that the relationship between the ratio of the financial leverage and dividend of the company is negative. In other words, as the risk and the financial leverage increase (decrease), the amount of the dividend of the Iranian companies decreases (increases). The results of the second hypothesis are consistent with the results of study 
conducted by Afza and Mirza (2010). Generally, the results indicate the confirmation of the first and second hypotheses of the study. In other words, there is a significant and positive relationship between the age of the company and the ratio of dividend and there is a significant and negative relationship between the ratio of the financial leverage and the dividend. The results also demonstrate a linear association between company age and dividend.

\section{References}

Afza, Talat, \& Mirza, Hammad Hassan. (2010). Ownership Structure and Cash Flows As Determinants of Corporate Dividend Policy in Pakistan. International Business Research, $3(3)$.

Ahmad, H., \& Javid, Attiya. (2009). Dynamics and Determinants of Dividend Policy in Pakistan: Evidence from Karachi Stock Exchange Non-Financial Listed Firms. International Research Journal of Finance and Economics, 25, 148-171.

Almazan, Andres, De Motta, Adolfo, Titman, Sheridan, \& Uysal, Vahap. (2010). Financial Structure, Acquisition Opportunities, and Firm Locations. The Journal of Finance, 65(2), 529-563. http://dx.doi.org/10.1111/j.1540-6261.2009.01543.x

Anthony, Joseph H., \& Ramesh, K. (1992). Association between accounting Performance Measures and Stock Prices: A Test of the Life Cycle Hypothesis. Journal of Accounting and Economics, 15(2-3), 203-227. http://dx.doi.org/10.1016/0165-4101(92)90018-W

Black, Ervin L. (1998). Life-Cycle Impacts on the Incremental Value-Relevance of Earnings and Cash Flow Measures. Journal of Financial Statement Analysis, 4, 40-57.

DeAngelo, Linda Elizabeth. (1981). Auditor Size and Audit Quality. Journal of Accounting and Economics, 3(3), 183-199. http://dx.doi.org/10.1016/0165-4101(81)90002-1

FASB, Financial Accounting Standard Board. (1978). Objective of Financial Reporting by Bussiness Enterprises Statement of Financial Accounting Concept No 1.

Ghorbani, Arash. (2006). Relationship between Earnings and Cash Flows with Firm's Value in Firm's Life Cycle Framework. (M. A. Dissertation), Islamic Azad University, Mashhad Branch.

Jenkins, David S, Kane, Gregory D., \& Velury, Uma. (2004). The Impact of the Corporate Life-Cycle on the Value-Relevance of disaggregated Earnings Components. Review of Accounting and Finance, 3(4), 5-20. http://dx.doi.org/10.1108/eb043411

John, Kose, \& Williams, Joseph. (1985). Dividends, Dilution, and Taxes: A Signalling Equilibrium. The Journal of Finance, 40(4), 1053-1070. http://dx.doi.org/10.1111/j.1540-6261.1985.tb02363.x

Lintner, John. (1956). Distribution of Incomes of Corporations among Dividends, Retained Earnings, and Taxes. American economic review, 46(2), 97-113. 


\section{Macrothink}

Asian Journal of Finance \& Accounting ISSN 1946-052X 2014, Vol. 6, No. 2

Mehrani, Kaveh. (2004). Relationship between Earnings Per Share, Dividend, and Investment in Listed Firms on Tehran Stock Exchange Iranian Accounting and Auditing Review, 36.

Stepanyan, Gohar G. (2011). Firm Life Cycle and the Choice of the form of Payout. Available at SSRN 1632834. http://dx.doi.org/10.2139/ssrn.1632834

Wang, Ming-Hui, Ke, Mei-Chu, Liu, Day-Yang, \& Huang, Yen-Sheng. (2011). Dividend Policy and the Life Cycle Hypothesis: Evidence from Taiwan. The International Journal of Business and Finance Research, 5(1), 33-52. 